tion among the judging members of the editorial board. Photomicrographs should be one column in width $\left(2 \frac{5}{8}\right.$ inches) so that they may be reproduced without reduction. Illustrations should be numbered, the tops indicated, and the author's name and the title of the article in brief appear on the back. A separate typewritten sheet of legends for the illustrations should be supplied.

Bibliography. Numbered references in alphabetical order should appear at the end of the manuscript with corresponding numbering in the text. Bibliographies should conform to the style of the Quarterly Cumulative Index Medicus, viz: author's name, title of article, name of journal, volume number, first and last page numbers, and year of publication in the order named.

\section{PUBLISHER'S NOTICES}

ChAnge of AdDRess: Please allow 60 days before date of issue for change of address. Notification should include the old as well as the new address, with indication of whether the change is temporary or permanent. Please give the name of the journal.

BUSINESS ADDRESS : Subscriptions, new or renewal advertising, and all business communications should be addressed to :

\section{Acta Cytologica}

The Williams \& Wilkins Co. 428 E. Preston St., Baltimore, Md. 21202, U.S.A.

Published bimonthly. Price $\$ 11.00$ per year United States funds, postpaid in the United States and its possessions; Canada, $\$ 11.50$. All other countries 11.75 . Single copies, 2.50 . Orders from the continent of Europe and the British Isles should be forwarded to A. S. Karger, A. G., Arnold Böcklinstr. 25, Basel, Switzerland.

The publishers accept po responsibility for opinions expressed by contributors.

本誌前号 6 巻 2 号<一般講演 $>10$ で, 発 表者が（岐阜大乾内 科）高井哲となっていますが，次のように訂正し，深く扔詑び 致します。

〔訂正〕（岐皁大乾内科）乾成美，杉浦陽太郎

安藤 成人, 高井 哲

（県立岐阜病院第 2 内科）林慶一 